\title{
mTOR kinase inhibitors synergize with histone deacetylase inhibitors to kill B-cell acute lymphoblastic leukemia cells
}

\author{
Brandon R. Beagle ${ }^{1}$, Duc M. Nguyen ${ }^{1}$, Sharmila Mallya ${ }^{1}$, Sarah S. Tang ${ }^{1}$, Mengrou \\ Lu $^{1}$, Zhihong Zeng ${ }^{2,3}$, Marina Konopleva ${ }^{2,3}$, Thanh-Trang Vo1 and David A. Fruman ${ }^{1}$ \\ ${ }^{1}$ Department of Molecular Biology \& Biochemistry, University of California, Irvine, CA \\ 2 Department of Leukemia, University of Texas MD Anderson Cancer Center, Houston, TX \\ ${ }^{3}$ Department of Stem Cell Transplantation and Cellular Therapy, University of Texas MD Anderson Cancer Center, Houston, \\ TX
}

Correspondence to: David A. Fruman, email: dfruman@uci.edu

Keywords: Leukemia, B-ALL, mTOR, histone deacetylase inhibitor

Received: November 17,2014 Accepted: December 11,2014 Published: December 12, 2014

This is an open-access article distributed under the terms of the Creative Commons Attribution License, which permits unrestricted use, distribution, and reproduction in any medium, provided the original author and source are credited.

\section{ABSTRACT}

High activity of the mechanistic target of rapamycin (mTOR) is associated with poor prognosis in pre-B-cell acute lymphoblastic leukemia (B-ALL), suggesting that inhibiting mTOR might be clinically useful. However, emerging data indicate that mTOR inhibitors are most effective when combined with other target agents. One strategy is to combine with histone deacetylase (HDAC) inhibitors, since B-ALL is often characterized by epigenetic changes that silence the expression of pro-apoptotic factors. Here we tested combinations of mTOR and pan-HDAC inhibitors on B-ALL cells, including both Philadelphia chromosome-positive $(\mathrm{Ph}+)$ and non-Ph cell lines. We found that mTOR kinase inhibitors (TOR-KIs) synergize with HDAC inhibitors to cause apoptosis in B-ALL cells and the effect is greater when compared to rapamycin plus HDAC inhibitors. The combination of TOR-KIs with the clinically approved HDAC inhibitor vorinostat increased apoptosis in primary pediatric B-ALL cells in vitro. Mechanistically, TOR-KI and HDAC inhibitor combinations increased expression of prodeath genes, including targets of the Forkhead Box 0 (FOXO) transcription factors, and increased sensitivity to apoptotic triggers at the mitochondria. These findings suggest that targeting epigenetic factors can unmask the cytotoxic potential of TORKIs towards B-ALL cells.

\section{INTRODUCTION}

B-ALL is the most common malignancy in children and also affects adults $[1,2]$. B-ALL is generally responsive to standard chemotherapy, but a subset of patients have poor prognosis. Among these high-risk cases, around $30 \%$ of adult B-ALL have the Philadelphia chromosome $(\mathrm{Ph}+)$; the percentage of $\mathrm{Ph}+$ is much lower in pediatric B-ALL. However, a subset of "Ph-like" B-ALLs have elevated tyrosine kinase activity [3-5], raising the possibility of treatment with TKIs or agents targeting downstream components like mTOR. Elevated mTOR signaling correlates with poor prognosis in B-ALL patients $[6,7]$, making it a promising therapeutic target.

The serine/threonine kinase mTOR has an important role in cell growth, proliferation and survival $[8,9]$.
mTOR integrates signals from growth factors, nutrient availability and cell stress to produce an appropriate cellular response to growth conditions. The mTOR enzyme acts in two distinct complexes, mTORC1 and mTORC2, with different regulation and downstream substrates $[8$, 10]. The classical mTOR inhibitor rapamycin (RAP) and its analogs (rapalogs) bind to an allosteric site in the mTORC1 complex and reduce mTORC1 activity towards some but not all substrates [11-13]. Newer ATPcompetitive mTOR kinase inhibitors (TOR-KIs) suppress phosphorylation of all mTORC1 and mTORC2 substrates $[14,15]$

In cancer cells, oncogene activation leads to elevated mTOR activity, promoting survival and biosynthetic processes necessary for cell division [1618]. There is strong interest in targeting mTOR for cancer 
therapy, in part based on genetic studies showing selective effects on tumor cells following mTOR inactivation [19, 20]. TOR-KIs have promising anti-tumor activity in preclinical models and several candidate compounds are in clinical trials [21-23]. Evidence is growing that TORKIs and rapalogs are most effective against cancer cells when used in combination with other therapies [24-28]. For example, we have reported that the tool compound PP242 and an investigation agent, MLN0128, potentiate the efficacy of tyrosine kinase inhibitors (TKIs) in B-ALL cells expressing the BCR-ABL oncoprotein [27, 28]. In a mouse BCR-ABL-dependent leukemia model, PP242 was more effective than RAP when combined with the BCRABL TKI imatinib [27].

Many B-ALLs carry translocations involving transcription factors [2], and genomic studies indicate that loss of histone acetyltransferases (HATs) is common [29, 30]. This suggests that targeting epigenetic factors, particularly histone deacetylases (HDAC), might have therapeutic benefit in B-ALL. The pan-HDAC inhibitor (HDACi) vorinostat is FDA-approved for cutaneous $\mathrm{T}$ cell lymphoma [31]. mTOR inhibitors have potential to suppress survival signaling, possibly enhancing the efficacy of HDACi. This concept is supported by preclinical studies of acute myeloid leukemia and hepatocellular carcinoma $[32,33]$, and is being tested in multiple clinical trials involving rapalogs combined with vorinostat or panobinostat (NCI clinical trial identifiers NCT00918333, NCT01341834, NCT01169532). A phase I trial of panobinostat and the rapalog everolimus reported $15 \%$ complete response rate in Hodgkins' lymphoma [34]. The effect of combining TOR-KIs and HDACi in B-ALL has not been reported.

We hypothesized that TOR-KIs might provide better efficacy than RAP when combined with HDACi in B-ALL. By blocking mTORC2, TOR-KIs reduce AKT activity and should increase the function of transcription factors in the Forkhead Box O (FOXO) family, leading to upregulation of pro-apoptotic genes [35]. We found that in human B-ALL cells, TOR-KIs are mainly cytostatic as single agents. Hence we tested whether HDACi could unleash the cytotoxic potential of TOR-KIs through epigenetic de-silencing of pro-apoptotic genes. The results show that HDACi increase the cytotoxic effects of TORKIs in B-ALL cell lines and primary B-ALL specimens. B-ALL cell killing by the HDACi/TOR-KI combination correlates with upregulation of FOXO target gene expression.

\section{RESULTS}

\section{mTOR inhibition promotes cell cycle arrest but not death of B-ALL cells}

TOR-KIs provide significant anti-leukemic effects in vitro and in vivo using both murine and human models of B-ALL [27, 28, 36]. Consistent with our previous study using PP242 [27], the clinical candidate compound MLN0128 [28] caused both cell death (Fig. 1A) and $\mathrm{G}_{0} /$ $\mathrm{G}_{1}$ arrest (Fig. 1C) in BCR-ABL-transformed murine pre-B cells ( $\mathrm{p} 190$ cells). In contrast, human $\mathrm{Ph}+$ cell lines (SUP-B15 and BV-173), Ph-negative cell lines (Nalm-6, Blin-1, RS11;4, 697, REH, SEM, Kasumi-2) and primary cells from bone marrow of pediatric B-ALL patients (Ph-negative) were less sensitive to MLN0128 induced cytotoxicity (Fig. 1A, 1B, 2A, 2B and Supplementary Figure S1). In agreement with our previous findings [27], TOR-KIs caused greater cell cycle arrest and death in p190 cells than rapamycin (Fig. 1A, C). Similarly, MLN0128 caused greater cell cycle arrest than rapamycin in SUP-B15 cells (Fig. 1C).

\section{HDAC inhibitors synergize with TOR-KIs to overcome B-ALL death resistance}

Clinically relevant concentrations of the FDAapproved HDACi, vorinostat [37-42], did not affect the viability of a panel of $\mathrm{Ph}+$ or non-Ph human B-ALL cell lines (Fig. 2A, 2B, S1). However, vorinostat significantly increased MLN0128-mediated cytotoxicity of $\mathrm{Ph}+$ and non-Ph B-ALL cell lines (Fig. 2A, 2B and S1). Similar results were obtained using distinct combinations of TOR-KIs with pan-HDACi: AZD8055 with vorinostat (Fig. S2A), MLN0128 with panobinostat (Fig. 2C), or MLN0128 with Apicidin (data not shown). The combination of MLN0128 plus vorinostat caused significantly more death than rapamycin plus vorinostat (Fig. S2B), indicating an advantage of TOR-KIs relative to rapamycin.

The MLN0128/vorinostat combination showed a strong synergistic effect in the $\mathrm{Ph}+$ cell line SUP-B15 (Fig. 2A) as well as the non-Ph cell line Nalm-6 (Fig. 2B). While the MLN0128/vorinostat combination enhanced cytotoxicity for all but one B-ALL cell line ( $\mathrm{REH}$, see Fig. S1) relative to single agent treatments, the magnitude of difference as well as inhibitor concentrations differed among the B-ALL cell lines. The heterogeneous response in cell lines prompted us to test the MLN0128/ vorinostat combination on primary B-ALL cells. For these experiments, we maintained survival of pediatric B-ALL specimens by culturing on immortalized stromal cells as described previously [28]. MLN0128 alone caused a small increase in B-ALL death (Fig. 3A), consistent with 
the data in Fig. 1A. Vorinostat alone had no effect, but significantly enhanced B-ALL killing when added together with MLN0128 in each individual primary B-ALL specimen (Fig. 3A).

\section{Survival of normal lymphocytes treated with TOR-KIs plus HDACi}

To evaluate the selectivity of the MLN0128/ vorinostat combination for leukemia cells, we applied this drug combination to peripheral blood mononuclear cells (PBMCs) from normal human donors. After $48 \mathrm{hr}$ of treatment, both MLN0128 (100 nM) and vorinostat (500 nM) slightly increased death of PBMC but the combination did not cause more death than MLN0128 alone (Fig. 3B). Gating on lymphocyte subpopulations showed that CD4+ $\mathrm{T}$ cells were largely resistant to MLN0128 or vorinostat alone or in combination (Fig. 3B). A significant but quantitatively small increase in killing was seen in the CD4-CD19- population (mostly CD8 T cells and natural killer cells) when treated with MLN0128 plus vorinostat. CD19+ B cells showed a high rate of spontaneous death following $48 \mathrm{hr}$ in vitro culture, and this was further increased by MLN0128 (Fig. 3B). Titrating MLN0128 (10 - $750 \mathrm{nM})$ and vorinostat $(50-3750 \mathrm{nM})$ confirmed greater effects on B cells than CD4+ T cells or CD4-CD19- cells (Fig. S3A, S3B).

Previously we reported that PP242 has minimal effects on survival and function of mouse $\mathrm{T}$ and $\mathrm{B}$ cells, when used at concentrations with anti-leukemic potential [27]. Similarly, MLN0128 at concentrations below 100 $\mathrm{nM}$ did not reduce survival of purified mouse splenic B cells cultured in the presence of cytokines IL-4 and BAFF (Fig. S3C). Vorinostat at concentrations below $1000 \mathrm{nM}$ had minimal effect on mouse B cell survival (Fig. S3C). MLN0128 (100 nM) did increase death of mouse B cells but this was not increased further by vorinostat $(500 \mathrm{nM})$ (Fig. 3C). The survival of mouse splenic T cells cultured in IL-7 and IL-15 was modestly reduced by treatment with MLN0128 and/or vorinostat (Fig. 3C, S3C). Overall these data suggest that MLN0128 and vorinostat, when combined at concentrations that cause B-ALL cell death, have little effect on human and mouse $\mathrm{T}$ cells but show cytotoxicity towards normal B cells.
A.

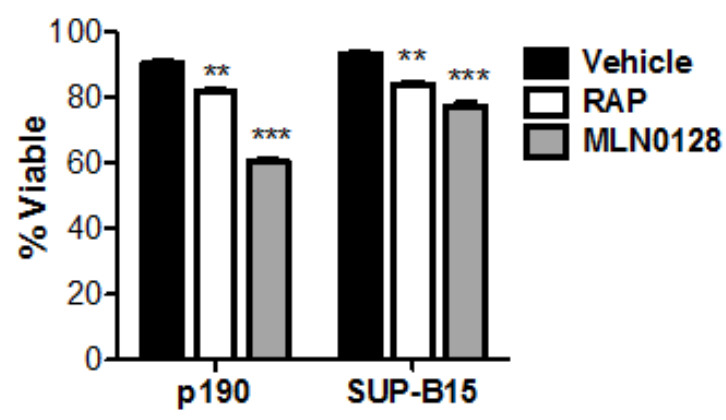

B.

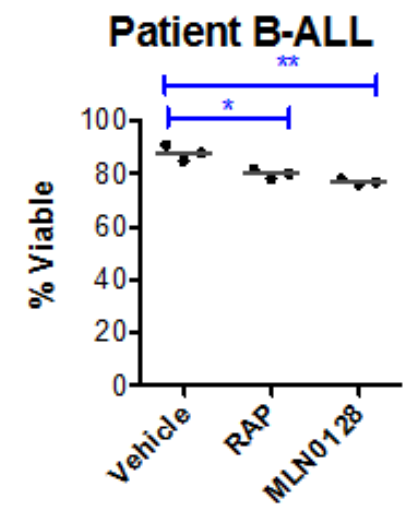

C.
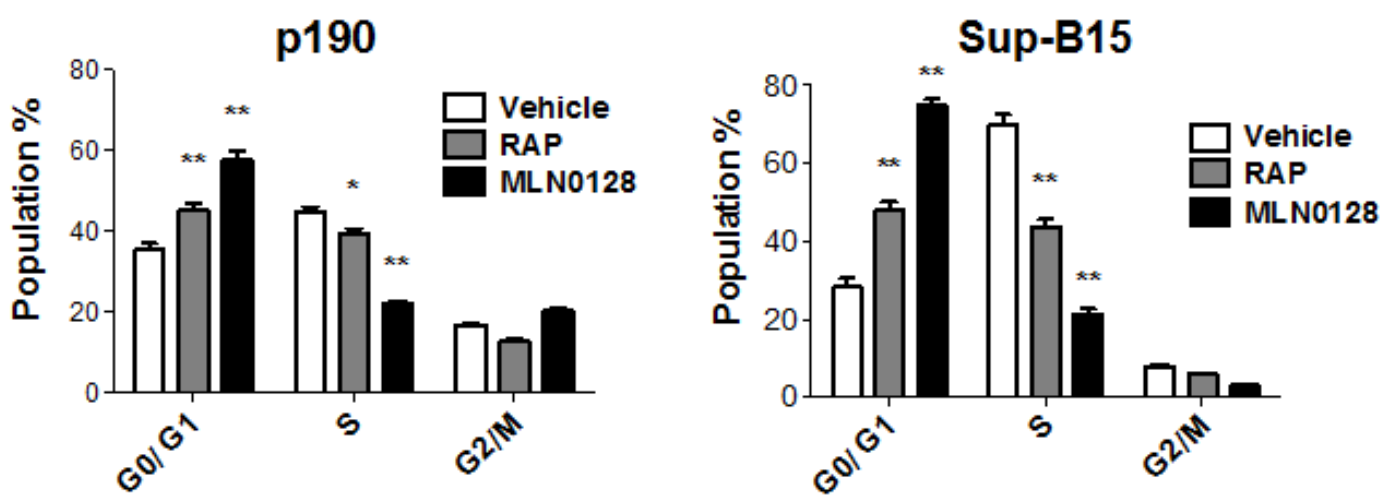

Figure 1: MLN0128 is mainly cytostatic in human B-ALL cells. (A) Cell lines (p190, SUP-B15) or (B) primary B-ALL cells ( $\mathrm{n}=3$ independent specimens) were cultured for $48 \mathrm{hr}$ with vehicle or with RAP or MLN0128. The percent viable cells was measured by 7-AAD staining and flow cytometry. For the primary patient samples, cells were grown on stromal cells and viability was determined for human CD19+ cells. (C) DNA content analysis was used to assess cell cycle distribution in p190 and SUP-B15 cells after 48 of culture. * $\mathrm{p}<0.05 ; * * \mathrm{p}<0.01, * * * \mathrm{p}<0.001$, one-way ANOVA. 


\section{MLN0128/vorinostat induces apoptosis in B-ALL cells}

B-ALL cell killing by combination treatment might induce cytotoxicity through necrosis or programmed cell death (i.e. apoptosis). The pan-caspase inhibitor QVD$\mathrm{OPH}$ caused a concentration-dependent suppression of apoptosis in SUP-B15 cells treated with MLN0128/ vorinostat (Fig. 4A), consistent with death by caspasedependent apoptosis. The combination of MLN0128/ vorinostat also increased PARP cleavage, a caspasedependent event in apoptotic cells (Fig. 4B). We did not consistently detect cleaved caspases by immunoblot or flow cytometry (data not shown), perhaps owing to low levels of caspase expression in B-ALL cells [43, 44]. However, using enzyme assays we observed a transient increase in activity of both caspase- 8 and caspase- 3 in three B-ALL cell lines treated with MLN0128/vorinostat that was significantly higher than in cells treated with single agents (Fig. S4). Together these data support apoptosis as the cytotoxic mechanism of action for the MLN0128/vorinostat combination in B-ALL cells.

\section{mTOR inhibition promotes transcriptional activity of the tumor suppressor, FOXO}

Broad spectrum HDACi like vorinostat have the potential to alter cellular signal transduction through altered transcription or non-histone target proteins. To investigate the mechanism of synergistic killing of B-ALL cells by MLN0128/vorinostat, we first assessed phosphorylation of signaling proteins in the PI3K/AKT/ mTOR pathway. As expected, vorinostat increased global histone acetylation in SUP-B15 cells; however, vorinostat did not affect phosphorylation of proteins in the PI3K/AKT/mTOR pathway (Fig. 5A). In contrast,
A.

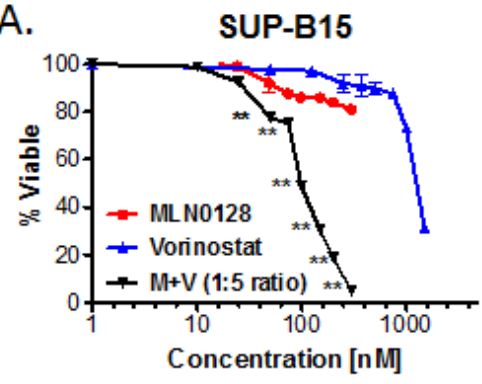

BV-173

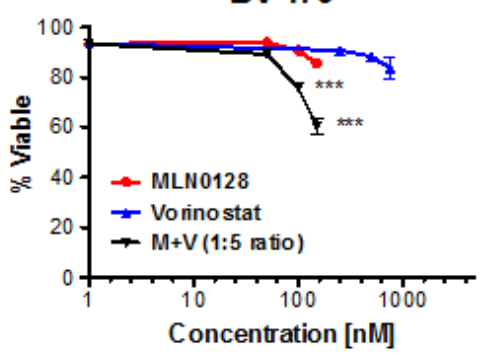

D.

SUP-B15 Combo Index

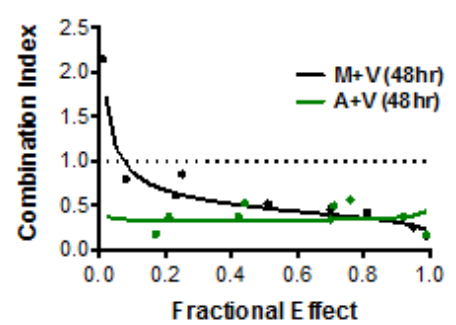

B.

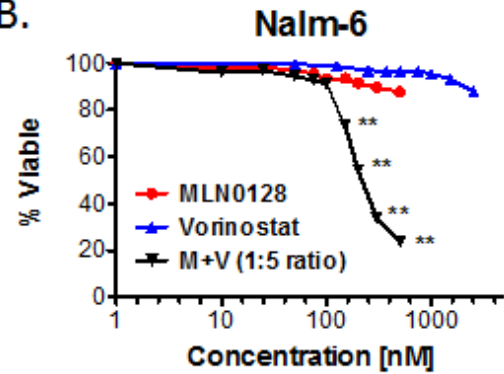

Blin-1

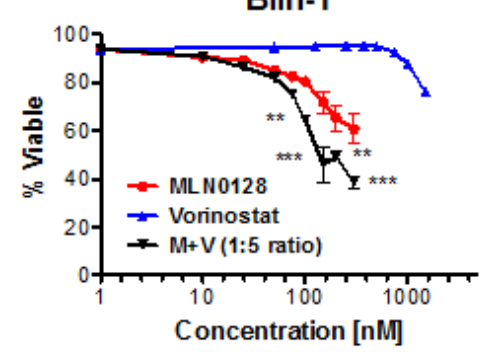

Nalm-6 Combo Index

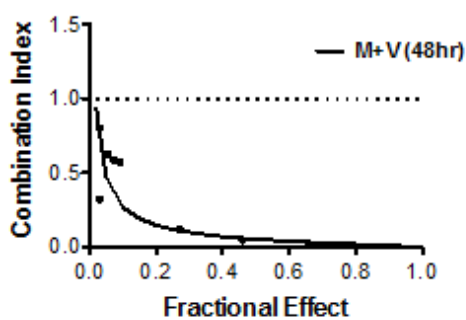

C.

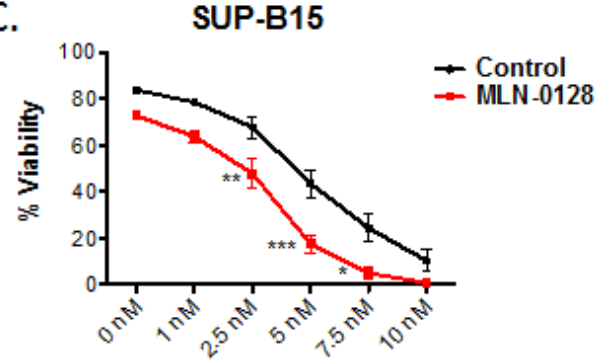

[Panobinostat] $\mathrm{nM}$

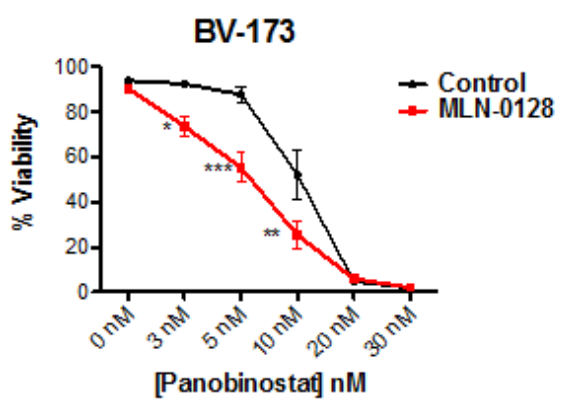

Figure 2: TOR-KIs and HDACi cause synergistic killing of B-ALL cell lines. (A) Two Ph+ B-ALL cell lines (SUP-B15 and BV173) were cultured for $48 \mathrm{hr}$ with titrated concentrations of MLN0128, vorinostat or both. Viability was measured by 7-AAD staining. For the combination treatment, the values represent the concentration of MLN0128 for that condition; vorinostat was present at 5 times this concentration (for example, $100 \mathrm{nM}$ MLN0128 and $500 \mathrm{nM}$ vorinostat). ${ }^{*} \mathrm{p}<0.05 ; * * \mathrm{p}<0.01$, two-way ANOVA. (B) Ph- B-ALL cell lines Nalm-6 and Blin-1 were analyzed as in panel A. (C) SUP-B15 and BV-173 cells were treated with the HDAC inhibitor panobinostat alone or in the presence of $100 \mathrm{nM}$ MLN0128. (D) SUP-B15 and Nalm-6 cells were treated with combinations of TOR-KIs and vorinostat at fixed ratios for $48 \mathrm{hr}$. Cell viability was determined, and the combination index for cell killing was calculated and graphed using Calcusyn software. The dashed line indicates a combination index of 1 . 
A.

Patient B-ALL in Co-Culture

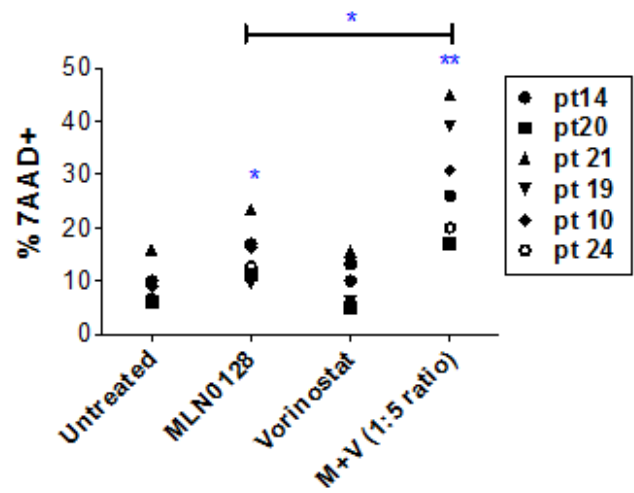

C.

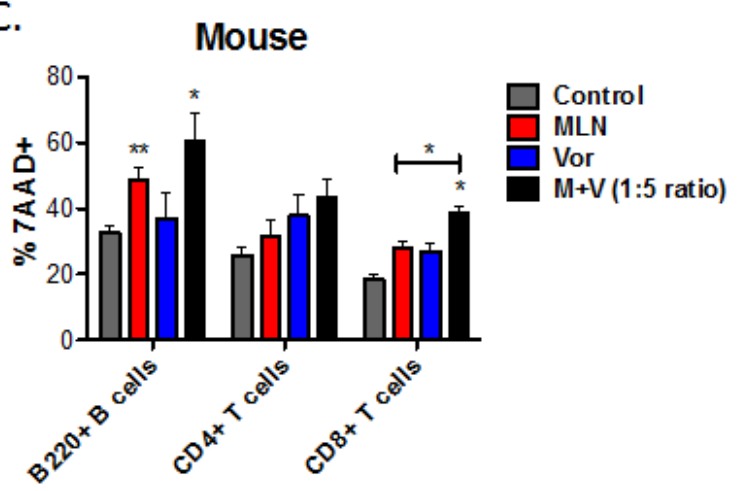

B.

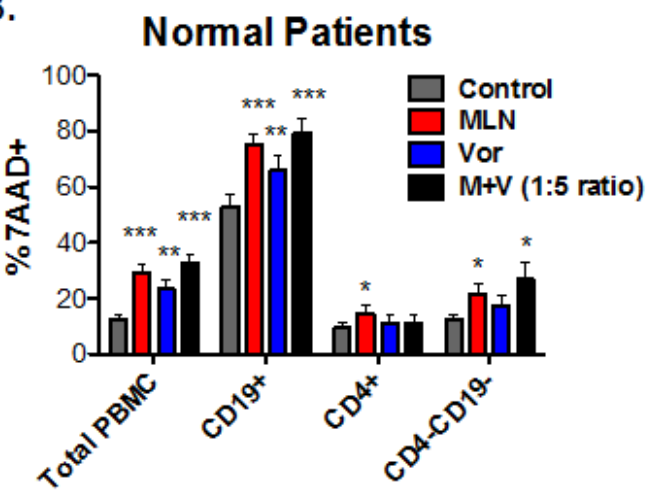

Figure 3: The combination of MLN0128/vorinostat increases killing of primary B-ALL cells with lesser effects on normal lymphocytes. (A) Six non-Ph B-ALL patient specimens were cultured on stromal cells in the absence or presence of MLN0128 $(100 \mathrm{nM})$, vorinostat $(500 \mathrm{nM})$ or the combination. FACS was used to determine the percentage of hCD19+ cells that were non-viable (7-AAD-positive) after 48hr. (B) PBMCs from normal human donors were cultured for 48hr in media without cytokines. Cells were stained with anti-CD4 to mark helper T cells and anti-CD19 to mark B cells. Cytotoxicity was measured as the percent 7-AAD-positive as in Figure 3A. Viability of total PBMCs was determined using the ungated cells. Viability of CD4+, CD19+, and CD4-CD19- cells (which comprise mainly CD $8+\mathrm{T}$ cells and natural killer cells) was determined using a lymphocyte gate based on forward and side scatter. Data represent mean +/- SEM $(n=5)$. (C) Purified mouse B-cells were cultured in BAFF and IL-4; purified T cells were cultured in IL-7 and IL-15. T cells were stained with anti-mouse CD4 and anti-mouse CD8 before viability analysis. Cytotoxicity was measured as the percent 7-AADpositive as in panels A and B. For all panels, ${ }^{*} \mathrm{p}<0.05 ; * * \mathrm{p}<0.01$, unpaired two-tailed t-test.
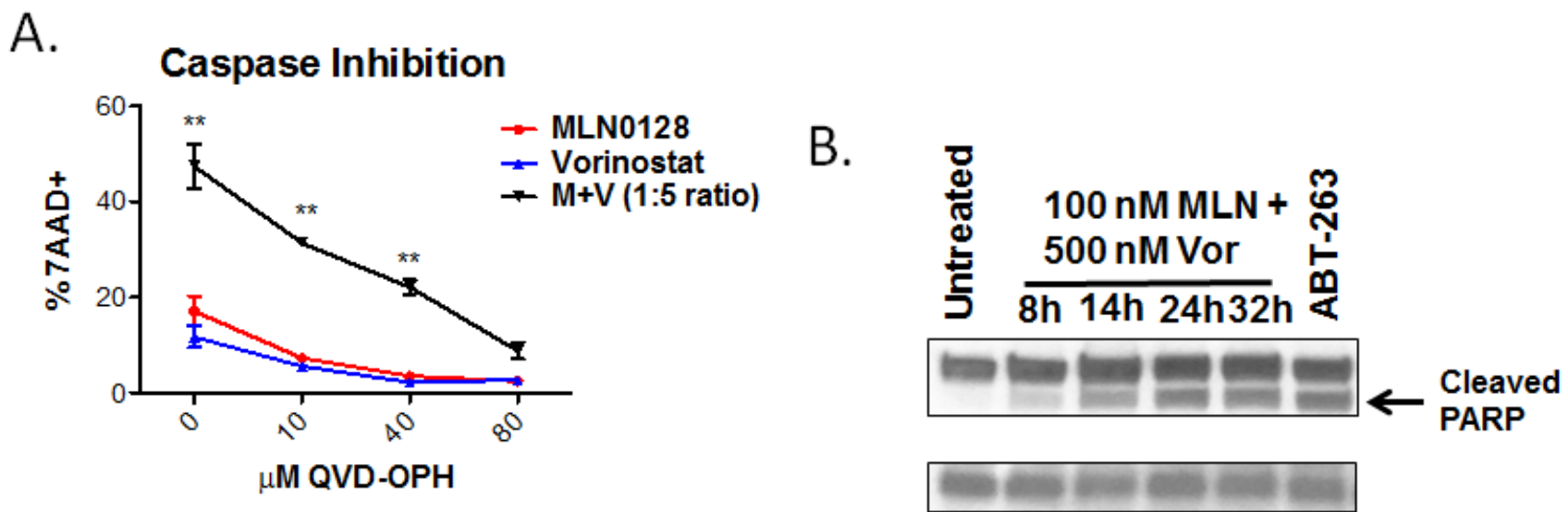

Figure 4: B-ALL cell death is caspase-dependent. (A) SUP-B15 cells were cultured with MLN0128 (100 nM), vorinostat (500 $\mathrm{nM})$, or the combination $(\mathrm{M}+\mathrm{V})$ in the presence of increasing concentrations of pan-caspase inhibitor. The percentage of cell death was determined after $48 \mathrm{hr}$ by 7-AAD staining (mean $+/$ - SEM, $\mathrm{n}=3-5$ ). $* \mathrm{p}<0.05 ; * * \mathrm{p}<0.01$, two-way ANOVA. (B) PARP cleavage in BV173 cells was measured by western blotting of lysates at various times after addition of MLN0128 (100 nM) and vorinostat (500 nM). Cells treated with the BCL2/BCL-XL antagonist ABT-263 were used as a positive control. $\beta$-actin served as a loading control. Similar results were observed in SUP-B15 cells. 
MLN0128 treatment reduced phosphorylation of the mTORC1 substrate 4EBP1 (T37/46) and the mTORC2 substrate AKT (S473), with only a slight effect on histone acetylation (Fig. 5A). MLN0128 also blocked phosphorylation of ribosomal protein S6 (S240/244) downstream of mTORC1 (Fig. 5A). Similar results were observed in the Blin-1 and Nalm- 6 cell lines (data not shown). MLN0128 and vorinostat did not influence ERK phosphorylation in SUP-B15 cells (Fig. 5A). These data suggest that vorinostat does not alter the activity of major oncogenic signaling pathways in B-ALL cell lines, nor does vorinostat modulate the signaling impact of TORKIs.

Next we considered possible changes in transcription factor activity. We noted that MLN0128 reduced phosphorylation of FOXO transcription factors in SUP-B15 cells (Fig. 5A). The FOXO family of transcription factors (FOXO1, FOXO3A, and FOXO4) function as redundant tumor suppressors in lymphocytes [45]. Activated AKT enters the nucleus and phosphorylates FOXO proteins, inhibiting their binding to DNA and promoting nuclear export [46]. Through this mechanism, $\mathrm{PI} 3 \mathrm{~K} / \mathrm{AKT}$ signaling prevents FOXO-mediated transcription of target genes that promote cell cycle arrest and apoptosis [47, 48]. Of the known AKT substrates, phosphorylation of FOXO proteins is particularly sensitive to reduced mTORC2 activity and AKT-S473 phosphorylation [49, 50]. As we observed previously in PP242-treated p190 cells [27], MLN0128 promoted nuclear localization of FOXO1 in SUP-B15 cells (Fig. $5 \mathrm{~B})$. This led us to investigate further the potential role of FOXO in the cytotoxic effects of MLN0128/vorinostat.

First we assessed expression of FOXO target genes. Treatment of SUP-B15 cells with MLN0128 strongly upregulated mRNA expression of the cell cycle inhibitors p27 and p130, with lesser effects on the proapoptotic targets BIM or TRAIL (Fig. 5C). Next we tested the potential of FOXO factors to regulate cell death in SUP-B15 cells. Inducible activation of constitutively active FOXO factors (FOXO1-A3 or FOXO3A-A3) increased cell death by $\sim 20 \%$ at $48 \mathrm{hr}$, and by $\sim 40 \%$ in combination with vorinostat (Fig. 5D). This indicates that forced activation of FOXO factors has a similar pro-death effect compared to TOR-KIs.

To obtain a broader view of gene expression changes following single or dual treatments, we used a PCR array to measure mRNAs for 90 genes regulating apoptosis. A heat map of the results shows that $8 \mathrm{hr}$ of treatment with
A.

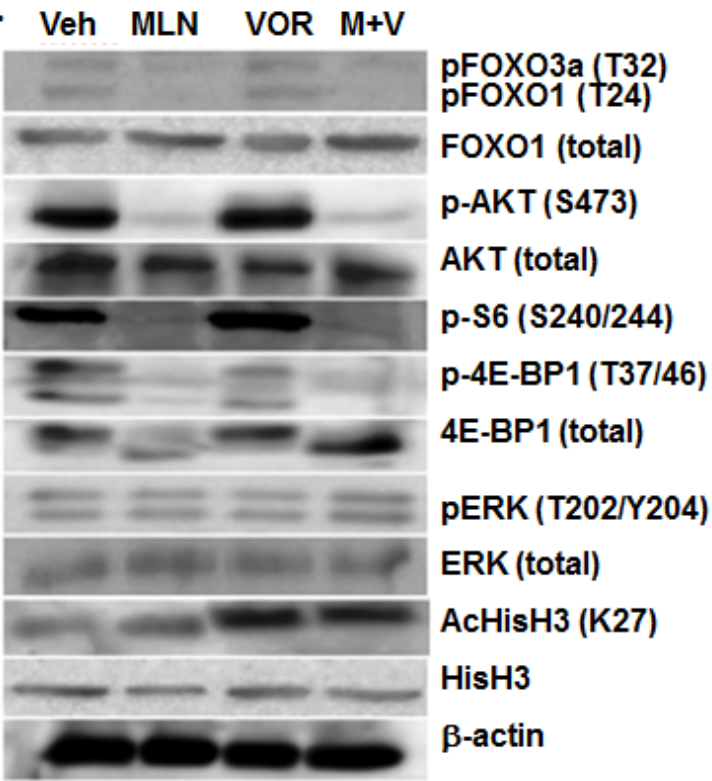

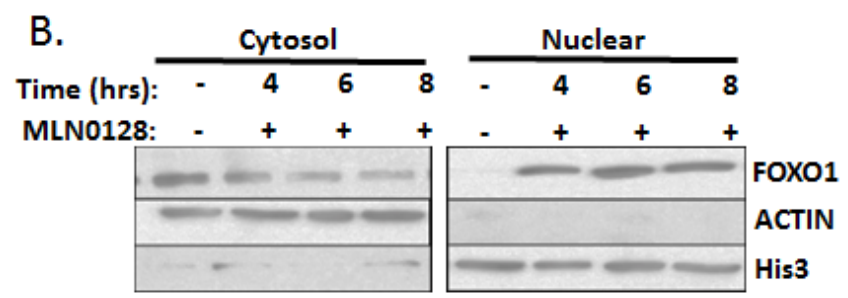

C. SUP-B15

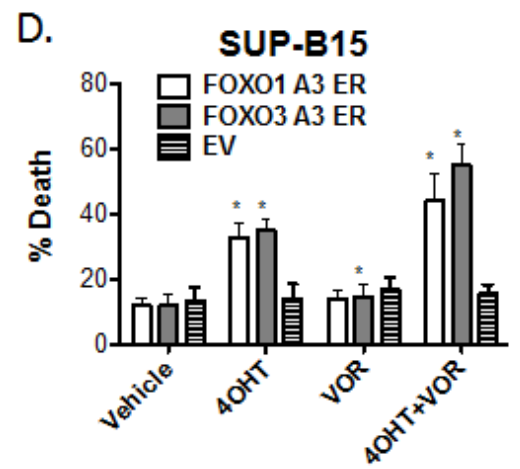

Figure 5: MLN0128 induces dephosphorylation and nuclear translocation of FOXO factors (A) Lysates from SUP-B15 cells treated for the indicated times with vehicle alone, MLN0128 (100 nM), vorinostat (500 nM), or the combination $(\mathbf{M}+\mathbf{V})$. Blots were probed for the proteins and phosphosites shown on the right. (B) SUP-B15 cells were treated for the indicated times with MLN0128 (100 nM) before cell fractionation into nuclear and cytoplasmic extracts. Fractions were subjected to western blotting with anti-FOXO1 antibody. Antibodies to $\beta$-actin and histone $\mathrm{H} 3$ were used to confirm the purity of cytoplasmic and nuclear fractions. (C) SUP-B15 cells were treated for $4 \mathrm{hr}$ with vehicle or $100 \mathrm{nM}$ MLN0128. mRNA was obtained and expression of the indicated gene products was determined by Q-PCR. Graph depicts the fold increase in mRNA in cells treated with MLN0128 versus vehicle $($ mean $+/-\mathrm{SEM}, \mathrm{n}=3$ ). *** $\mathrm{p}<0.001$, one-way ANOVA. BIM and TRAIL mRNA was not increased at 6 or $8 \mathrm{hr}$ post-treatment (not shown). (D) SUP-B15 cells were infected with retroviruses expressing a human CD4 marker gene lacking the cytoplasmic tail and magnetically sorted to enrich hCD4+ cells. The vectors contained no insert (EV) or cDNAs encoding triple-alanine mutants of FOXO1 or FOXO3a fused to the hormone binding domain of the estrogen receptor (ER). Cells were then treated with vehicle or $4 \mathrm{OHT}$ for $48 \mathrm{hr}$ in the absence or presence of vorinostat (500 $\mathrm{nM}$ ). The percentage of cell death was determined after $48 \mathrm{hr}$ by 7 -AAD staining (mean $+/-\mathrm{SEM}, \mathrm{n}=3$ ). ${ }^{*} \mathrm{p}<0.05$; paired two-tailed t-test. 
vorinostat broadly increased expression of pro-apoptotic genes while reducing expression of pro-survival genes (Fig. S5). Combined treatment with vorinostat and MLN0128 also increased mRNA expression of a number of pro-apoptotic genes (Fig. S5). Several of these genes are known FOXO targets: FASLG (Fas ligand), GADD45A, TNFSF10 (TRAIL), TNFRSF10A (death receptor-4 (DR4)), TNFRSF10B, (death receptor-5 (DR5)), BNIP3L. Of note, vorinostat alone altered expression of many genes to a similar or greater extent than the combination (Fig. S5). Therefore, it is likely that a complex reprogramming of gene expression drives cell death sensitivity in cells treated with TOR-KIs plus HDACi.

\section{Combining TOR-KIs and HDACi increases mitochondrial priming for death}

Due to the complex changes in gene transcription, we wanted to obtain a more direct understanding of how the drug combinations affect overall survival signaling at the mitochondria by using a $\mathrm{BH} 3$ profiling assay. The experimental approach involves treating permeabilized cells with fixed doses of death signals in the form of peptides made from the $\mathrm{BH} 3$ domain of pro-apoptotic BCL-2 family proteins, and measuring mitochondrial depolarization as in indicator of apoptosis initiation. An increase in the ratio of pro-apoptotic to anti-apoptotic factors at the mitochondria augments sensitivity to BH3 peptides and is termed mitochondrial "priming". We found that $16 \mathrm{hr}$ of treatment with MLN0128/vorinostat significantly increased priming in four different B-ALL cell lines (Fig. 6). Interestingly, the cell lines varied in their response to individual drugs. These differences are best seen in the conditions where lower concentrations of Bim peptide $(0.1 \mu \mathrm{M})$ or PUMA peptide $(5 \mu \mathrm{M})$ were added. For example, vorinostat alone increased priming in Blin-1 and Kasumi but had little or no effect in BV173 or SUP-B15 (Fig. 6). This variability, together with the PCR array data, suggests that the death mechanism triggered in B-ALL cells by MLN0128/vorinostat is complex and varies among cell lines. The identity of the pro-apoptotic genes upregulated by each inhibitor may vary depending on the particular epigenome and kinome
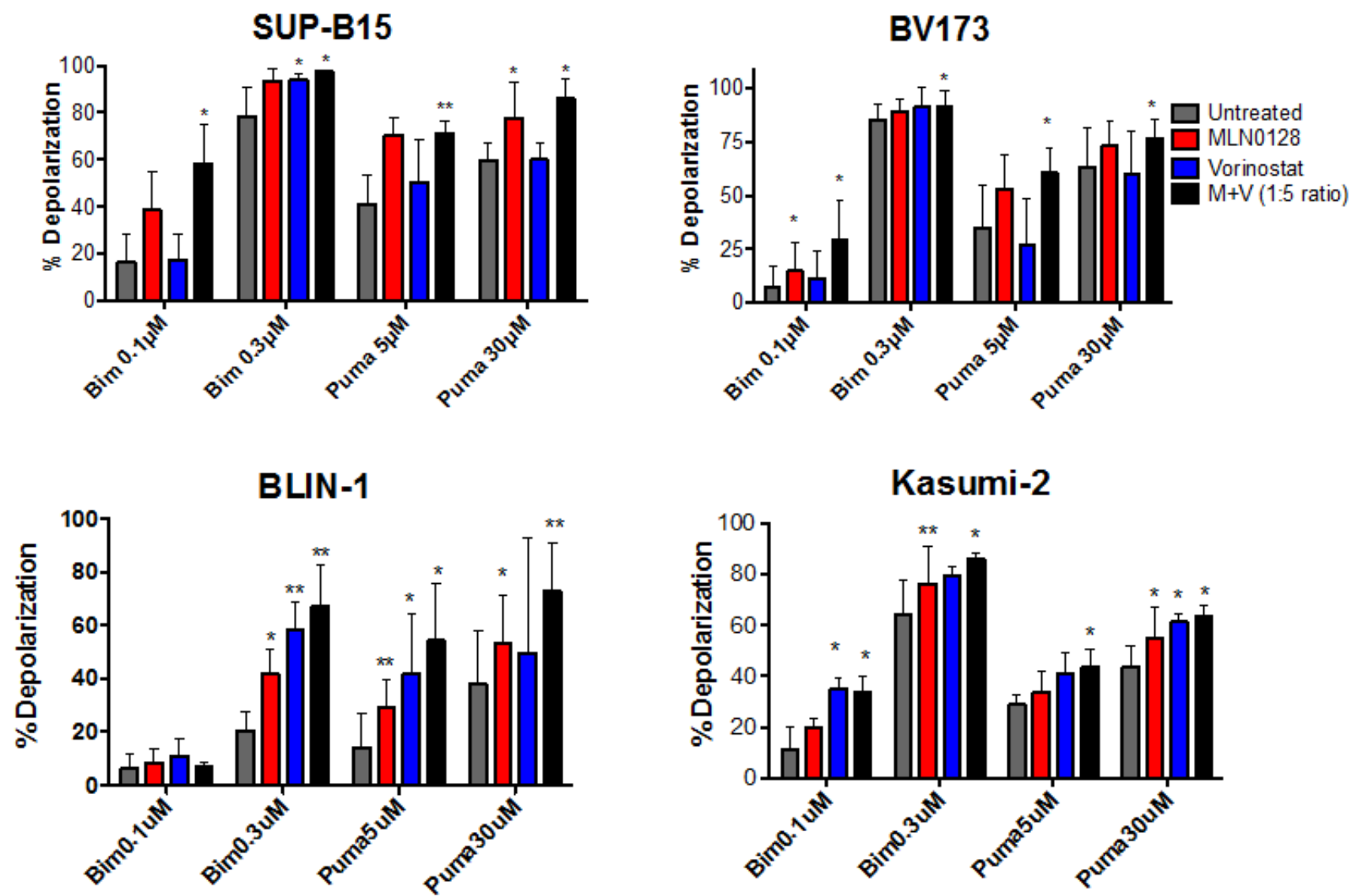

Figure 6: BH3 profiling assay shows increased mitochondrial priming in B-ALL cells treated with MLN0128/vorinostat. Two Ph+ (SUP-B15 and BV173) and two non-Ph (BLIN-1 and Kasumi-2) B-ALL cell lines were subjected to BH3 profiling assay 16hr after treatment with vehicle (labeled untreated), MLN0128 (100 nM), vorinostat (500 nM), or the combination. Increase in mitochondrial depolarization is a quantitative measure of mitochondrial apoptosis initiation. In all lines, the combination increases the cells, sensitivity to pro-apoptotic BH3 peptides more than either agent alone. Percent depolarization of cells by each peptide is graphed. $($ mean $+/-\mathrm{SD})$. $\mathrm{n}=$ $3-5 ;$ * p-value $<0.05$; paired one-tailed t-test. 
of the cells. Regardless, in all cases the combination produced the greatest overall increase in priming, which correspondingly accounts for some of the synergy we observed in B-ALL cell killing.

\section{DISCUSSION}

Inhibitors of the PI3K/AKT/mTOR pathway hold promise for treating cancer, and may be most effective when used in combination with other agents [25]. For example, rapalogs have demonstrated limited single agent activity in human cancer patients but provide significant clinical benefit in hormone-dependent breast cancer when given in combination with aromatase inhibitors [24]. We showed previously that combining TOR-KIs with tyrosine kinase inhibitors is effective in preclinical models of $\mathrm{Ph}+$ B-ALL $[27,28]$. Here we report that cytotoxic potential of TOR-KIs in B-ALL can be augmented by pan-HDAC inhibitors such as vorinostat or panobinostat. The synergistic effect is observed in $\mathrm{Ph}+$ and non-Ph B-ALL cell lines as well as primary pediatric B-ALL.

Our data suggest that FOXO transcription factors may play a role in the death mechanism. FOXO proteins help to maintain quiescence in CML stem cells [51] and can promote apoptosis in CML cells treated with $\mathrm{ABL}$ tyrosine kinase inhibitors $[52,53]$. TOR-KI treatment causes nuclear localization of FOXO proteins in B-ALL cells, shown here in SUP-B15 cells and previously in mouse p190 cells [27]. Moreover, we found that inducible expression of AKT-independent, constitutively active FOXO variants (FOXO1-A3, FOXO3a-A3) caused some cell death in SUP-B15 cells that was further increased by vorinostat, in the absence of TOR-KI treatment.

A plausible model is that HDACi treatment induces epigenetic changes that facilitate access of FOXO transcription factors to pro-apoptotic target genes in B-ALL cells. Results from the PCR array suggested broad reprogramming of gene expression by vorinostat alone or in combination with MLN0128. These changes result in B-ALL killing through activation of caspase-dependent apoptosis. The transient elevation of both caspase- 8 and caspase- 3 activity suggests that an extrinsic death pathway is involved. However, TRAIL was not required for B-ALL cell death in response to the MLN0128/vorinostat combination (data not shown). It is possible that multiple death receptors and ligands contribute to apoptosis.

The synergistic effect of TOR-KIs plus HDACi is greater than achieved using rapamycin plus HDACi. TOR-KIs are more effective inhibitors of mTORC2 but also suppress phosphorylation of rapamycin-resistant mTORC1 substrates, such as 4EBP1 [15, 22]. Hence, it is likely that the AKT-FOXO axis downstream of mTORC2 is not the only relevant target of TOR-KIs for achieving synergy with HDACi. By phosphorylating 4EBP1, mTORC1 promotes cap-dependent translation of mRNAs encoding pro-survival proteins (e.g. MCL-1)
[8]. mTORC1 also controls transcription of metabolic genes to maintain cancer cell survival and proliferation [54]. The precise mechanism of synergy between TORKIs and HDACi might differ among B-ALL cell lines, depending on varying histone acetylation patterns. In support of this, the BH3 profiling assay showed that single agent treatment with MLN0128 or vorinostat had variable effects on mitochondrial priming among four cell lines tested. Previous reports of synergistic anti-cancer effects of HDACi with PI3K/mTOR pathway inhibitors have identified distinct mechanisms of tumor cell killing among different blood cancers [32, 55-58], further supporting the idea that the mechanisms of synergy are contextdependent.

Although vorinostat is an FDA-approved treatment for cutaneous $\mathrm{T}$ cell lymphoma, evidence is accumulating that drugs of this class have a limited therapeutic window especially in combination regimens. A clinical trial of panobinostat with everolimus in relapsed/refractory lymphoma resulted in some objective responses but a high rate of adverse events including thrombocytopenia [34]. A clinical trial of panobinostat monotherapy in Hodgkin's Lymphoma patients who relapse after transplant reported some efficacy but considerable hematotoxicity [59]. Our data show that the combination of MLN0128 plus vorinostat strongly reduces viability of B-ALL cells but also affects normal B-lymphocytes from humans and mice. Broad changes in the translational landscape may be a double-edged sword that increases B-ALL killing but also increases normal cell toxicity or suppresses cellular function. For example, vorinostat suppresses cellular immune responses mediated by human NK cells and T lymphocytes [60]. Refinements in drug selectivity might improve further the selectivity for leukemia cells. Agents targeting a single HDAC isoform or subgroup might maintain synergy with TOR-KIs in leukemia cells while preserving normal physiological cell functions. Overall our results show that the combination of TOR-KIs and HDACi can be a viable treatment for B-ALL, but the resulting broad changes in the transcriptional landscape may call for the use of more isoform-selective HDAC inhibitors to limit toxicity.

\section{MATERIALS AND METHODS}

\section{Materials}

MLN0128 was purchased from Active Biochem (Hong Kong), PP242 and AZD8055 from Chemdea (Ridgewood, NJ). Using cell-based assays we verified that MLN0128 and PP242 from these vendors had comparable activity as compounds provided under a Material Transfer Agreement by Intellikine (synthesized as previously described [28]). Vorinostat was purchased from LC 
laboratories, and panobinostat from Selleck. Antibodies and flow cytometry reagents were obtained from Cell Signaling, Invitrogen, eBioscience and Biolegend. TRAIL R2/DR5 agonist or soluble TRAIL antagonist antibodies were purchased from Enzo Life Science or R\&D Systems.

\section{Cell Lines}

Generation and propagation of pre-B p190 mouse cells have been previously described [27]. Nalm6 and Blin-1 cell lines were kindly provided by Dr. David Rawlings (University of Washington), and the RS11;4, SEM, and 697 cell lines by Dr. Anthony Letai (Harvard Med. School). The $\mathrm{Ph}+$ cell lines SUP-B15, Tom-1, BV-173 and non-Ph lines REH and Kasumi-2 were purchased from ATCC and DSMZ. Except for the p190 cells, all described cells represent human pre-B cell acute lymphoblastic leukemia (B-ALL). All cells were maintained at $37^{\circ} \mathrm{C}$ in $5 \% \mathrm{CO} 2$, and RPMI 1640 supplemented with 1\% L-glutamine, $1 \%$ Pen/Strep, $0.5 \%$ HEPES, $0.1 \%$ beta-mercaptoethanol and 10\% FBS.

\section{Mice}

$\mathrm{Balb} / \mathrm{c}$ and $\mathrm{C} 57 \mathrm{Bl} / 6$ mice were kept in specific pathogen-free animal facilities at the University of California, Irvine, and procedures were approved by the Institutional Animal Care and Use Committee. We used 3-5 week old male and female Balb/c mice to obtain bone marrow for generation of p190 cell lines. 6-12 week old $\mathrm{C} 57 \mathrm{Bl} / 6$ mice were used to isolate $\mathrm{B}$ and $\mathrm{T}$ cells from spleen and lymph node.

\section{Flow cytometry (FACS)}

Surface phenotyping was performed and analyzed with methods previously described [27]. Data was acquired using FACSCaliber (Becton Dickinson) and analyzed with FlowJo software version 9.5.2.

\section{Normal mouse and human lymphocytes}

Deidentified peripheral blood samples were obtained from normal donors. PBMCs were purified using a Ficoll gradient and 0.5 million cells per condition were treated with MLN0128 and/or vorinostat in $1 \mathrm{~mL}$ of media (RPMI1640 supplemented with 1\% L-glutamine, 1\% Pen/ Strep, 0.5\% HEPES, 0.1\% beta-mercaptoethanol and 10\% FBS). After 48 hours of treatment, cells were stained with hCD19-PE (Biolegend), hCD4-FITC (BD Bioscience), human TruStain FcX (Biolegend) and 7-AAD. Mouse splenic B cells were purified using EasySep Mouse B Cell Isolation Kit (Stem Cell Techology) from wildtype C57BL/6 mice. Cells were plated at 1 million per
mL (RPMI1640 supplemented with 1\% L-glutamine, 1\% Pen/Strep, $0.5 \%$ HEPES, $0.1 \%$ beta-mercaptoethanol, $10 \% \mathrm{FBS}, 60 \mathrm{ng} / \mathrm{mL}$ BAFF and $20 \mathrm{ng} / \mathrm{nL}$ IL-4) in 96 well plates at $100 \mu \mathrm{L}$ final volume per condition. Cells were treated with MLN0128 and/or vorinostat for 48 hours and stained with B220-AlexaFluor488 (eBioscience), mouse TruStain FcX (Biolegend) and 7-AAD. Lymph nodes were harvested from C57BL/6 mice and plated at 2 million per $\mathrm{mL}$ in media supplemented with $10 \mathrm{ng} / \mathrm{mL}$ IL-7 and $10 \mathrm{ng} / \mathrm{mL}$ IL-15 in 48 well plate at $300 \mu \mathrm{L}$ final volume per condition. Cells were treated with MLN0128 and/or vorinostat for 48 hours and stained with CD8-PE (eBioscience), CD4-FITC (eBioscience), mouse TruStain FcX (Biolegend) and 7-AAD.

\section{Primary leukemia samples and stromal co- cultures}

We obtained bone marrow from newly diagnosed pediatric B-ALL patients at CHOC Children's Hospital under Institutional Review Board protocols approved by $\mathrm{CHOC}$ and by UC Irvine. Leukocytes were isolated from these pediatric specimens by centrifugation over Ficoll and stored frozen in aliquots. For stromal coculture experiments, hTERT-immortalized human marrow stromal cell (MSC) $\left(10^{4}\right)$ (provided by D. Campana, St. Jude's Children's Research Hospital) were plated in 96 well plates in RPMI1640+10\% FBS containing $1 \mu \mathrm{M}$ hydrocortisone (Sigma). The following day, the media was replaced, and $10^{5}$ B-ALL cells were plated with hTERT-MSCs in AIM-V media (Life Technologies) with $10 \%$ FBS supplemented with human SCF, IL-3, IL-7, and FLT-3L (Peprotech) at $100 \mathrm{ng} / \mathrm{ml}$. The co-cultures were immediately treated with indicated inhibitors/drugs. Fortyeight hrs post-treatment, cells were manually dislodged, stained with human CD19-FITC (Biolegend) and 7-AAD (Life Technologies) and immediately analyzed by flow cytometry.

\section{Western Blot and Nuclear Fractionation}

Western blot and nuclear fractionations were performed as previously described [27, 61]. Except for anti-Actin (Sigma), all indicated antibodies were purchased from Cell Signaling.

\section{RNA Extraction, cDNA Synthesis and qPCR}

Total RNA was isolated using the TRIZOL method (Invitrogen). To quantify transcript levels, equal amounts of cDNA were synthesized using the iScript cDNA synthesis kit (Bio-Rad) and mixed with the SYBR Advantage qPCR Premix (Clontech) and run on the iCycler iQ ${ }^{\mathrm{TM}}$ Real-Time PCR Detection system (BioRad). 
All primers for identified genes were designed using the open access PrimerBank software (pga.mgh.harvard. edu/primerbank). All samples were done in duplicate or triplicate. The $2^{-\Delta \Delta \mathrm{Ct}}$ was used to determine fold change in mRNA levels relative to vehicle control samples (DMSO). L32 was amplified as the internal control. The Apoptotic PCR Array (Qiagen) was performed as per manufacturers instructions.

\section{Cell Cycle and Cell Death}

Cell cycle analysis was performed as previously described [27]. Briefly, cell cultures were washed with cell cycle buffer (PBS containing $5 \mathrm{mM}$ EDTA) and subsequently fixed with ice-cold $70 \% \mathrm{EtOH}$ dropwise while being vortexed (medium setting). Cells were fixed overnight at $-20^{\circ} \mathrm{C}$. Samples were subsequently washed with cell cycle buffer and incubated with $2 \mathrm{mg} \mathrm{ml}-1$ RNase A solution for $3 \mathrm{hr}$ at RT. Cells were then stained with prodium iodide $(0.5 \mathrm{mg} / \mathrm{ml})$ for $1 \mathrm{hr}$ at RT. The DNA fluorescence parameter (585/42 $\mathrm{nm}$ bandpass) using linear amplification was collected on a FACS Caliber equipped with a $488 \mathrm{~nm}$ laser line. Doublets and aggregates were excluded by pulse width versus area.

Cell death was analyzed for all indentified B-ALL cell lines and primary patient samples using 7-AAD/ forward scatter (FSC) FACS analysis as previously described [62]. Gating of vehicle control samples (DMSO) was used to identify viable vs. non-viable cells. The results of 7-AAD/FSC analysis corresponded with PI/AnnexinV-FITC (Biolegend) when tested (data not shown). As previously shown by others, immunoblot analysis of cleaved caspase -9 or -3 in parental B-ALL cell lines such as SUP-B15, Nalm-6, REH-1, etc. is unreliable in detecting death by apoptosis [43, 44]. Therefore, we used the specific and highly sensitive [63-65] Luciferase Caspase-Glo ${ }^{\circledR}-8$ or $-3 / 7$ Assay Systems (Promega) to determine kinetic caspase- $3 / 7$ or -8 activation as per the manufacturers instructions. For caspase inhibitor studies, the pan-capsase inhibitor Q-VD-OPH (R\&D Systems) was incubated at concentrations identified in the figure legend concomitantly with inhibitor/drug treatment and cell viability via 7-AAD/FSC was analyzed 48 hrs posttreatment.

\section{Inducible FOXO expression}

Triple alanine mutants of FOXO1 and FOXO3A (FOXO1-A3, FOXO3A-A3) fused to the hormonebinding domain of the estrogen receptor (ER) were the gift of Dr. Boudewijn Burgering (University of Utrecht). The cDNAs were subcloned into the retroviral vector MSCV-IRES-hCD4 to drive bicistronic expression of the FOXO protein and a truncated human CD4 lacking the cytoplasmic tail. 293T cells were plated in IMDM medium and were $\sim 80 \%$ confluent at time of transfection. Next 2.5 $\mu \mathrm{g}$ of the FOXO A3 ER or empty vector construct and 2.5 $\mu \mathrm{g}$ of pCL Ampho packaging vector were combined with XtremeGene HP DNA transfection reagent (Roche) before adding dropwise to $293 \mathrm{~T}$ cells. The cells were incubated at $37^{\circ} \mathrm{C}$ and the medium replaced at $24 \mathrm{hrs}$. At $48 \mathrm{hrs}$, viral supernatant was collected and centrifuged to remove any $293 \mathrm{~T}$ cells in suspension. For spinfection, SUP-B15 cells in log phase of growth were resuspended in the viral supernatant and $10 \mu \mathrm{g} / \mathrm{mL}$ of polybrene. The cells were centrifuged in a 6 well plate at $500 \mathrm{x} \mathrm{g}$ and $37^{\circ} \mathrm{C}$ for 2 hrs and incubated at $37^{\circ} \mathrm{C}$ overnight. Viral supernatant was then replaced with regular growth medium and the cells rested for a day. The spinfection protocol was repeated a total of 3 times. Infected SUP-B15 cells were resuspended in MACS Buffer (PBS, 2mM EDTA, 0.5\% BSA) and labeled with anti-hCD4 biotin antibody (1.0 $\mu \mathrm{g} / 1 \times 10^{6}$ cells; eBioscience) for $10 \mathrm{mins}$ at $4 \mathrm{oC}$. Labeled cells were pelleted, resuspended in MACS Buffer, and conjugated with anti-biotin microbeads $\left(10 \mu \mathrm{L} / 1 \times 10^{7}\right.$ cells; Miltenyi). The cell suspension was loaded into a MS MACS separation column (Miltenyi Biotec) to purify only CD4+ SUP-B15 cells. To induce expression, purified SUP-B15 cells were plated at $4 \times 10^{5}$ cells in $2 \mathrm{~mL}$ in a 12 well plate and treated with DMSO control, $200 \mathrm{nM}$ 4-OHT, $500 \mathrm{nM}$ Vorinostat, or 4-OHT+Vorinostat. After 48 hours, cells were labeled with anti-hCD4 Alexa 647 antibody (Biolegend) and 7-AAD. 7-AAD/FSC analysis was performed on hCD4+ cells using the BD FACSCaliber to detect cell viability.

\section{BH3 Profiling}

B-ALL cell lines were incubated with no inhibitor, $100 \mathrm{nM}$ MLN0128, $500 \mathrm{nM}$ of vorinostat, or the combination for 16 hours. BH3 profiling was performed as described in Vo et al [66]. Briefly, cells were washed in PBS and resuspended at $2 \times 10^{6}$ per $\mathrm{mL}$ of (TEB) Trehalose Experimental Buffer (300 mM trehalose, $1 \mathrm{mM}$ EDTA, $1 \mathrm{mM}$ EGTA, $5 \mathrm{mM}$ succinic acid, 0.1\% BSA-IgG free, $10 \mathrm{mM}$ HEPES, $80 \mathrm{mM} \mathrm{KCl}$ ). Next $100 \mu \mathrm{L}$ of cells was combined with $100 \mu \mathrm{L}$ of TEB containing $\mathrm{BH} 3$ peptides (Bim or Puma), $20 \mathrm{ug} / \mathrm{mL}$ oligomycin, $0.005 \%$ digitonin. Then $25 \mu \mathrm{L}$ of JC-1 (900 nM stock) was added. These components were incubated at room temperature for 90 minutes and red JC-1 (FL2 channel) aggregates were detected in each cell by FACS analysis immediately after.

\section{Statistical analysis}

Two-way ANOVA was used with Tukey-Kramer post-hoc analysis for cell viability experiments. For BH3 profiling, a paired t-test was done to compare untreated versus each treatment group for each peptide to show how each treatment affects basal priming. We used GraphPad 
Prism (5.0c) software for all statistical analysis. To determine whether inhibitor combinations were additive, synergistic, or antagonistic, we used the Chou and Talalay median effects analysis to calculate a combination index (CI) using CalcuSyn v1 software (Biosoft) as described [67].

\section{ACKNOWLEDGEMENTS}

This work was supported by Cancer Center Support Grant P30-CA062203 (to D.A.F.), and by NIH grants R01CA158383 (to D.A.F.), T32-CA9054 (to B.B. and T.T.V.), F32-CA189629 (to T.T.V.) and P50-CA100632 (to Z.Z.; Leukemia SPORE Career Development Award). D.A.F. also received support from the University of California Office of the President (UC Discovery Grant 192418).

\section{REFERENCES}

1. Pui CH, Mullighan CG, Evans WE and Relling MV. Pediatric acute lymphoblastic leukemia: where are we going and how do we get there? Blood. 2012; 120(6):1165-1174.

2. Pui CH, Robison LL and Look AT. Acute lymphoblastic leukaemia. Lancet. 2008; 371(9617):1030-1043.

3. Loh ML, Zhang J, Harvey RC, Roberts K, Payne-Turner D, Kang H, Wu G, Chen X, Becksfort J, Edmonson M, Buetow KH, Carroll WL, Chen IM, Wood B, Borowitz MJ, Devidas M, et al. Tyrosine kinome sequencing of pediatric acute lymphoblastic leukemia: a report from the Children's Oncology Group TARGET Project. Blood. 2013; 121(3):485-488.

4. Roberts KG, Li Y, Payne-Turner D, Harvey RC, Yang YL, Pei D, McCastlain K, Ding L, Lu C, Song G, Ma J, Becksfort J, Rusch M, Chen SC, Easton J, Cheng J, et al. Targetable kinase-activating lesions in $\mathrm{Ph}$-like acute lymphoblastic leukemia. N Engl J Med. 2014; 371(11):1005-1015.

5. Roberts KG, Morin RD, Zhang J, Hirst M, Zhao Y, Su X, Chen SC, Payne-Turner D, Churchman ML, Harvey RC, Chen X, Kasap C, Yan C, Becksfort J, Finney RP, Teachey DT, et al. Genetic alterations activating kinase and cytokine receptor signaling in high-risk acute lymphoblastic leukemia. Cancer Cell. 2012; 22(2):153-166.

6. Meyer LH, Eckhoff SM, Queudeville M, Kraus JM, Giordan M, Stursberg J, Zangrando A, Vendramini E, Moricke A, Zimmermann M, Schrauder A, Lahr G, Holzmann K, Schrappe M, Basso G, Stahnke K, et al. Early relapse in ALL is identified by time to leukemia in NOD/SCID mice and is characterized by a gene signature involving survival pathways. Cancer Cell. 2011; 19(2):206-217.

7. Nemes K, Sebestyen A, Mark A, Hajdu M, Kenessey I, Sticz T, Nagy E, Barna G, Varadi Z, Kovacs G, Kopper $\mathrm{L}$ and Csoka M. Mammalian target of rapamycin (mTOR) activity dependent phospho-protein expression in childhood acute lymphoblastic leukemia (ALL). PLoS ONE. 2013; 8(4):e59335.

8. Laplante M and Sabatini DM. mTOR signaling in growth control and disease. Cell. 2012; 149(2):274-293.

9. $\mathrm{Vu} \mathrm{C}$ and Fruman DA. Target of rapamycin signaling in leukemia and lymphoma. Clin Cancer Res. 2010; 16(22):5374-5380.

10. Cybulski $\mathrm{N}$ and Hall MN. TOR complex 2: a signaling pathway of its own. Trends Biochem Sci. 2009; 34(12):620627.

11. Hsu PP, Kang SA, Rameseder J, Zhang Y, Ottina KA, Lim D, Peterson TR, Choi Y, Gray NS, Yaffe MB, Marto JA and Sabatini DM. The mTOR-regulated phosphoproteome reveals a mechanism of mTORC1-mediated inhibition of growth factor signaling. Science. 2011; 332(6035):13171322.

12. Kang SA, Pacold ME, Cervantes CL, Lim D, Lou HJ, Ottina K, Gray NS, Turk BE, Yaffe MB and Sabatini DM. mTORC1 phosphorylation sites encode their sensitivity to starvation and rapamycin. Science. 2013; 341(6144):1236566.

13. Yu Y, Yoon SO, Poulogiannis G, Yang Q, Ma XM, Villen J, Kubica N, Hoffman GR, Cantley LC, Gygi SP and Blenis J. Phosphoproteomic analysis identifies Grb10 as an mTORC1 substrate that negatively regulates insulin signaling. Science. 2011; 332(6035):1322-1326.

14. Feldman ME, Apsel B, Uotila A, Loewith R, Knight ZA, Ruggero D and Shokat KM. Active-site inhibitors of mTOR target rapamycin-resistant outputs of mTORC1 and mTORC2. PLoS Biol. 2009; 7(2):e38.

15. Thoreen CC, Kang SA, Chang JW, Liu Q, Zhang J, Gao Y, Reichling LJ, Sim T, Sabatini DM and Gray NS. An ATP-competitive mammalian target of rapamycin inhibitor reveals rapamycin-resistant functions of mTORC1. J Biol Chem. 2009; 284(12):8023-8032.

16. Dazert E and Hall MN. mTOR signaling in disease. Curr Opin Cell Biol. 2011; 23(6):744-755.

17. Guertin DA and Sabatini DM. Defining the role of mTOR in cancer. Cancer Cell. 2007; 12(1):9-22.

18. Silvera D, Formenti SC and Schneider RJ. Translational control in cancer. Nat Rev Cancer. 2010; 10(4):254-266.

19. Guertin DA, Stevens DM, Saitoh M, Kinkel S, Crosby $\mathrm{K}$, Sheen JH, Mullholland DJ, Magnuson MA, Wu H and Sabatini DM. mTOR complex 2 is required for the development of prostate cancer induced by Pten loss in mice. Cancer Cell. 2009; 15(2):148-159.

20. Nardella C, Carracedo A, Alimonti A, Hobbs RM, Clohessy JG, Chen Z, Egia A, Fornari A, Fiorentino M, Loda M, Kozma SC, Thomas G, Cordon-Cardo C and Pandolfi PP. Differential requirement of $\mathrm{mTOR}$ in postmitotic tissues and tumorigenesis. Sci Signal. 2009; 2(55):ra2.

21. Benjamin D, Colombi M, Moroni C and Hall MN. Rapamycin passes the torch: a new generation of mTOR inhibitors. Nat Rev Drug Discov. 2011; 10(11):868-880.

22. Janes MR and Fruman DA. Targeting TOR dependence in 
cancer. Oncotarget. 2010; 1:69-76.

23. Wander SA, Hennessy BT and Slingerland JM. Nextgeneration mTOR inhibitors in clinical oncology: how pathway complexity informs therapeutic strategy. J Clin Invest. 2011; 121(4):1231-1241.

24. Baselga J, Campone M, Piccart M, Burris HA, 3rd, Rugo HS, Sahmoud T, Noguchi S, Gnant M, Pritchard KI, Lebrun F, Beck JT, Ito Y, Yardley D, Deleu I, Perez A, Bachelot $\mathrm{T}$, et al. Everolimus in postmenopausal hormone-receptorpositive advanced breast cancer. N Engl J Med. 2012; 366(6):520-529.

25. Fruman DA and Rommel C. PI3K and cancer: lessons, challenges, and opportunities. Nat Rev Drug Discov. 2014; 13(2):140-56

26. Garcia-Garcia C, Ibrahim YH, Serra V, Calvo MT, Guzman M, Grueso J, Aura C, Perez J, Jessen K, Liu Y, Rommel C, Tabernero J, Baselga J and Scaltriti M. Dual mTORC1/2 and HER2 blockade results in antitumor activity in preclinical models of breast cancer resistant to anti-HER2 therapy. Clin Cancer Res. 2012; 18(9):2603-2612.

27. Janes MR, Limon JJ, So L, Chen J, Lim RJ, Chavez MA, $\mathrm{Vu}$ C, Lilly MB, Mallya S, Ong ST, Konopleva M, Martin MB, Ren P, Liu Y, Rommel C and Fruman DA. Effective and selective targeting of leukemia cells using a TORC1/2 kinase inhibitor. Nat Med. 2010; 16(2):205-213.

28. Janes MR, Vu C, Mallya S, Shieh MP, Limon JJ, Li LS, Jessen KA, Martin MB, Ren P, Lilly MB, Sender LS, Liu Y, Rommel $\mathrm{C}$ and Fruman DA. Efficacy of the investigational mTOR kinase inhibitor MLN0128/INK128 in models of B-cell acute lymphoblastic leukemia. Leukemia. 2013; 27(3):586-594.

29. Inthal $A$, Zeitlhofer $P$, Zeginigg $M$, Morak $M$, Grausenburger R, Fronkova E, Fahrner B, Mann G, Haas $\mathrm{OA}$ and Panzer-Grumayer R. CREBBP HAT domain mutations prevail in relapse cases of high hyperdiploid childhood acute lymphoblastic leukemia. Leukemia. 2012; 26(8):1797-1803.

30. Mullighan CG, Zhang J, Kasper LH, Lerach S, PayneTurner D, Phillips LA, Heatley SL, Holmfeldt L, CollinsUnderwood JR, Ma J, Buetow KH, Pui CH, Baker SD, Brindle PK and Downing JR. CREBBP mutations in relapsed acute lymphoblastic leukaemia. Nature. 2011; 471(7337):235-239.

31. Zain J and O'Connor OA. Targeting histone deacetyalses in the treatment of B- and T-cell malignancies. Invest New Drugs. 2010; 28 Suppl 1:S58-78.

32. Nishioka C, Ikezoe T, Yang J, Koeffler HP and Yokoyama A. Blockade of mTOR signaling potentiates the ability of histone deacetylase inhibitor to induce growth arrest and differentiation of acute myelogenous leukemia cells. Leukemia. 2008; 22(12):2159-2168.

33. Shao H, Gao C, Tang H, Zhang H, Roberts LR, Hylander BL, Repasky EA, Ma WW, Qiu J, Adjei AA, Dy GK and $\mathrm{Yu}$ C. Dual targeting of mTORC1/C2 complexes enhances histone deacetylase inhibitor-mediated anti-tumor efficacy in primary $\mathrm{HCC}$ cancer in vitro and in vivo. J Hepatol. 2012; 56(1):176-183.

34. Oki Y, Buglio D, Fanale M, Fayad L, Copeland A, Romaguera J, Kwak LW, Pro B, de Castro Faria S, Neelapu S, Fowler N, Hagemeister F, Zhang J, Zhou S, Feng L and Younes A. Phase I study of panobinostat plus everolimus in patients with relapsed or refractory lymphoma. Clin Cancer Res. 2013; 19(24):6882-6890.

35. Bean GR, Ganesan YT, Dong Y, Takeda S, Liu H, Chan PM, Huang Y, Chodosh LA, Zambetti GP, Hsieh JJ and Cheng EH. PUMA and BIM are required for oncogene inactivation-induced apoptosis. Sci Signal. 2013; 6(268):ra20.

36. Carayol N, Vakana E, Sassano A, Kaur S, Goussetis DJ, Glaser H, Druker BJ, Donato NJ, Altman JK, Barr S and Platanias LC. Critical roles for mTORC2- and rapamycininsensitive mTORC1-complexes in growth and survival of BCR-ABL-expressing leukemic cells. Proc Natl Acad Sci U S A. 2010; 107(28):12469-12474.

37. Bolden JE, Peart MJ and Johnstone RW. Anticancer activities of histone deacetylase inhibitors. Nat Rev Drug Discov. 2006; 5(9):769-784.

38. Tay K, Dunleavy K and Wilson WH. Novel agents for B-cell non-Hodgkin lymphoma: science and the promise. Blood Rev. 2010; 24(2):69-82.

39. Lane AA and Chabner BA. Histone deacetylase inhibitors in cancer therapy. J Clin Oncol. 2009; 27(32):5459-5468.

40. Ma X, Ezzeldin HH and Diasio RB. Histone deacetylase inhibitors: current status and overview of recent clinical trials. Drugs. 2009; 69(14):1911-1934.

41. Tycko B. Cancer epigenetics and targeted therapies. Oncology. 2011; 25(3):228, 231.

42. Venugopal B and Evans TR. Developing histone deacetylase inhibitors as anti-cancer therapeutics. Curr Med Chem. 2011; 18(11):1658-1671.

43. Romanski A, Bacic B, Bug G, Pfeifer H, Gul H, Remiszewski S, Hoelzer D, Atadja P, Ruthardt M and Ottmann OG. Use of a novel histone deacetylase inhibitor to induce apoptosis in cell lines of acute lymphoblastic leukemia. Haematologica. 2004; 89(4):419-426.

44. Mazumder S, Choudhary GS, Al-Harbi S and Almasan A. Mcl-1 Phosphorylation defines ABT-737 resistance that can be overcome by increased NOXA expression in leukemic B cells. Cancer Res. 2012; 72(12):3069-3079.

45. Paik JH, Kollipara R, Chu G, Ji H, Xiao Y, Ding Z, Miao L, Tothova Z, Horner JW, Carrasco DR, Jiang S, Gilliland DG, Chin L, Wong WH, Castrillon DH and DePinho RA. FoxOs are lineage-restricted redundant tumor suppressors and regulate endothelial cell homeostasis. Cell. 2007; 128(2):309-323.

46. Calnan DR and Brunet A. The FoxO code. Oncogene. 2008; 27(16):2276-2288.

47. Burgering BM. A brief introduction to FOXOlogy. 
Oncogene. 2008; 27(16):2258-2262.

48. Eijkelenboom A and Burgering BM. FOXOs: signalling integrators for homeostasis maintenance. Nat Rev Mol Cell Biol. 2013; 14(2):83-97.

49. Guertin DA, Stevens DM, Thoreen CC, Burds AA, Kalaany NY, Moffat J, Brown M, Fitzgerald KJ and Sabatini DM. Ablation in mice of the $\mathrm{mTORC}$ components raptor, rictor, or $\mathrm{mLST} 8$ reveals that $\mathrm{mTORC} 2$ is required for signaling to Akt-FOXO and PKCalpha, but not S6K1. Dev Cell. 2006; 11(6):859-871.

50. Jacinto E, Facchinetti V, Liu D, Soto N, Wei S, Jung SY, Huang Q, Qin J and Su B. SIN1/MIP1 maintains rictormTOR complex integrity and regulates Akt phosphorylation and substrate specificity. Cell. 2006; 127(1):125-137.

51. Naka K, Hoshii T, Muraguchi T, Tadokoro Y, Ooshio T, Kondo Y, Nakao S, Motoyama N and Hirao A. TGF-betaFOXO signalling maintains leukaemia-initiating cells in chronic myeloid leukaemia. Nature. 2010; 463(7281):676680.

52. Essafi A, Fernandez de Mattos S, Hassen YAM, Soeiro I, Mufti GJ, Thomas NSB, Medema RH and Lam EWF. Direct transcriptional regulation of $\mathrm{Bim}$ by FoxO3a mediates STI571-induced apoptosis in Bcr-Abl-expressing cells. Oncogene. 2005; 24(14):2317-2329.

53. Komatsu N, Watanabe T, Uchida M, Mori M, Kirito K, Kikuchi S, Liu Q, Tauchi T, Miyazawa K, Endo H, Nagai T and Ozawa K. A Member of Forkhead Transcription Factor FKHRL1 Is a Downstream Effector of STI571-induced Cell Cycle Arrest in BCR-ABL-expressing Cells. J Biol Chem. 2003; 278(8):6411-6419.

54. Yecies JL and Manning BD. mTOR links oncogenic signaling to tumor cell metabolism. J Mol Med. 2011; 89(3):221-228.

55. Dong LH, Cheng S, Zheng Z, Wang L, Shen Y, Shen ZX, Chen SJ and Zhao WL. Histone deacetylase inhibitor potentiated the ability of MTOR inhibitor to induce autophagic cell death in Burkitt leukemia/lymphoma. J Hematol Oncol. 2013; 6:53.

56. Gupta M, Ansell SM, Novak AJ, Kumar S, Kaufmann SH and Witzig TE. Inhibition of histone deacetylase overcomes rapamycin-mediated resistance in diffuse large B-cell lymphoma by inhibiting Akt signaling through mTORC2. Blood. 2009; 114(14):2926-2935.

57. Qian C, Lai CJ, Bao R, Wang DG, Wang J, Xu GX, Atoyan R, Qu H, Yin L, Samson M, Zifcak B, Ma AW, DellaRocca S, Borek M, Zhai HX, Cai X, et al. Cancer network disruption by a single molecule inhibitor targeting both histone deacetylase activity and phosphatidylinositol 3-kinase signaling. Clin Cancer Res. 2012; 18(15):41044113.

58. Simmons JK, Patel J, Michalowski A, Zhang S, Wei BR, Sullivan P, Gamache B, Felsenstein K, Kuehl WM, Simpson RM, Zingone A, Landgren O and Mock BA. TORC1 and class I HDAC inhibitors synergize to suppress mature B cell neoplasms. Mol Oncol. 2014; 8(2):261-272.

59. Younes A, Sureda A, Ben-Yehuda D, Zinzani PL, Ong TC, Prince HM, Harrison SJ, Kirschbaum M, Johnston P, Gallagher J, Le Corre C, Shen A and Engert A. Panobinostat in patients with relapsed/refractory Hodgkin's lymphoma after autologous stem-cell transplantation: results of a phase II study. J Clin Oncol. 2012; 30(18):2197-2203.

60. Stephen S, Morrissey KA, Benoit BM, Kim EJ, Vittorio CC, Nasta SD, Showe LC, Wysocka M and Rook AH. Inhibition of cell-mediated immunity by the histone deacetylase inhibitor vorinostat: implications for therapy of cutaneous T-cell lymphoma. Am J Hematol. 2012; 87(2):226-228.

61. Beagle B and Johnson GV. Differential modulation of TCF/ LEF-1 activity by the soluble LRP6-ICD. PLoS ONE. 2010; 5(7):e11821.

62. Duy C, Hurtz C, Shojaee S, Cerchietti L, Geng H, Swaminathan S, Klemm L, Kweon SM, Nahar R, Braig M, Park E, Kim YM, Hofmann WK, Herzog S, Jumaa H, Koeffler HP, et al. BCL6 enables Ph+ acute lymphoblastic leukaemia cells to survive BCR-ABL1 kinase inhibition. Nature. 2011; 473(7347):384-388.

63. Finlay D, Richardson RD, Landberg LK, Howes AL and Vuori K. Novel HTS strategy identifies TRAIL-sensitizing compounds acting specifically through the caspase- 8 apoptotic axis. PLoS ONE. 2010; 5(10):e13375.

64. Hummon AB, Pitt JJ, Camps J, Emons G, Skube SB, Huppi K, Jones TL, Beissbarth T, Kramer F, Grade M, Difilippantonio MJ, Ried T and Caplen NJ. Systems-wide RNAi analysis of CASP8AP2/FLASH shows transcriptional deregulation of the replication-dependent histone genes and extensive effects on the transcriptome of colorectal cancer cells. Mol Cancer. 2012; 11:1.

65. Liu J, Uematsu H, Tsuchida N and Ikeda MA. Essential role of caspase- 8 in p53/p73-dependent apoptosis induced by etoposide in head and neck carcinoma cells. Mol Cancer. 2011; 10:95.

66. Vo TT, Ryan J, Carrasco R, Neuberg D, Rossi DJ, Stone RM, Deangelo DJ, Frattini MG and Letai A. Relative mitochondrial priming of myeloblasts and normal HSCs determines chemotherapeutic success in AML. Cell. 2012; 151(2):344-355.

67. Chou TC. Drug combination studies and their synergy quantification using the Chou-Talalay method. Cancer Res. 2010; 70(2):440-446. 